The World Turned 



\section{The World Turned}

Essays on Gay History, Politics, and Culture

\section{John D’Emilio}

DUKE UNIVERSITY PRESS Durbam and London 2002 
(C) 2002 Duke University Press

All rights reserved

Printed in the United States of

America on acid-free paper $\infty$

Designed by Amy Ruth Buchanan

Typeset in Carter \& Cone Galliard

by Keystone Typesetting, Inc.

Library of Congress Cataloging-inPublication Data appear on the last printed page of this book.

THE DISTRIBUTION OF THIS

BOOK IS SUPPORTED BY A

GENEROUS GRANT FROM THE GILL FOUNDATION. 
FOR JIM 
